\title{
Effect of oral and intravenous iron therapy on hemoglobin levels in hemodialysis patients according to serum ferritin level
}

\author{
Shoichiro Daimon ${ }^{1 *}$ and Ichiro Mizushima ${ }^{2}$
}

\begin{abstract}
Background: For iron therapy in hemodialysis patients, intravenous rather than oral administration is recommended.

Methods: For hemodialysis patients with serum ferritin levels less than $200 \mathrm{ng} / \mathrm{ml}$ (less than $100 \mathrm{ng} / \mathrm{ml}: 67$ patients, between 100 and $199 \mathrm{ng} / \mathrm{ml}: 20$ patients) with no iron therapy for more than 3 months, iron was administered intravenously ( $40 \mathrm{mg}$ of ferric oxide saccharate for ten times consecutively, $N=40$ ) or orally ( $50 \mathrm{mg} /$ day of sodium ferrous citrate $N=31$, or $1500 \mathrm{mg} /$ day of ferric citrate hydrate $N=16$ ). We conducted the retrospective observational study to evaluate the changes in hemoglobin levels, the dose of erythropoietin-stimulating agents (ESAs), and the ratio of ESA dose/hemoglobin ( $\mathrm{Hb}$ ) levels for 28 weeks.

Results: During the first 8 weeks, hemoglobin levels increased and ESA/Hb ratio decreased uniformly with almost the same ESA dose. Subsequently, ESA/Hb ratio increased in patients with intravenous iron but decreased further in patients administered oral iron. ESA dose reduction at the end of the study in the patients receiving intravenous iron, sodium ferrous citrate, and ferric citrate hydrate were 12.2, 33.8, and $39.5 \%$, and ESA/Hb reduction ratios were 10.3, 34. 5 , and $37.4 \%$, respectively. In patients with serum ferritin levels less than $100 \mathrm{ng} / \mathrm{ml}$ at baseline, ESA/Hb ratio decreased especially in those receiving oral rather than intravenous iron $(p<0.05)$, while it did not change with either oral or intravenous iron in patients with serum ferritin levels between 100 and $199 \mathrm{ng} / \mathrm{ml}$.

Conclusions: In hemodialysis patients with serum ferritin levels less than $100 \mathrm{ng} / \mathrm{ml}$, oral iron therapy is an effective method to treat anemia.
\end{abstract}

Keywords: Hemodialysis, Ferritin, Anemia, Iron, Erythropoietin-stimulating agents

\section{Background}

Anemia is common in hemodialysis patients, and a relative deficiency of erythropoietin (EPO) is the predominant cause [1]. Anemia management in hemodialysis patients was revolutionized by the introduction of erythropoietinstimulating agents (ESAs) in the late 1980s and has become the mainstay of anemia treatment [2]. With the introduction of ESAs, iron deficiency has become an important component of anemia in hemodialysis patients [3]. Although intravenous (IV) iron administration can supply iron to hemodialysis patients irrespective of their

\footnotetext{
* Correspondence: dai-clinic@m2.spacelan.ne.jp

'Department of Nephrology, Daimon Clinic for Internal Medicine,

Nephrology and Dialysis, Oshino 1-400, Nonoichi 921-8802, Japan

Full list of author information is available at the end of the article
}

condition, this method can enhance the risk of iron toxicity, and associations between high doses of IV iron and cardiovascular disease, infection, hospitalization, and death have been reported [4, 5]. Although oral iron supplementation is supposed to be more physiologic than that by the IV route, several studies have indicated that IV iron is superior to oral iron in hemodialysis patients [6,7], and IV administration is widely recommended $[8,9]$. Despite the copious evidences regarding the superiority of IV over oral iron for the treatment of anemia, some exceptions exist. In some centers in Canada, the efficacy of oral iron therapy in long-term hemodialysis patients was investigated, with equivalent efficacy between predominantly oral and IV iron administration reported [10]. 
Here, we evaluated the effect of oral iron supplementation on anemia by comparing when iron is administered intravenously.

\section{Methods}

This study focused on stable hemodialysis patients in Daimon Clinic for Internal Medicine, Nephrology and Dialysis. Patients who had received blood transfusion or iron supplementation within 3 months were excluded. Serum ferritin levels were evaluated every 12 weeks, and $50 \mathrm{mg} /$ day of sodium ferrous citrate was administered if serum ferritin levels were less than $200 \mathrm{ng} / \mathrm{ml}$ (less than $100 \mathrm{ng} / \mathrm{ml}$ in principle, but also between 100 and $199 \mathrm{ng} / \mathrm{ml}$ if serum ferritin levels were never below $100 \mathrm{ng} / \mathrm{ml}$ without iron administration for more than 3 months) and hemoglobin levels were less than $12 \mathrm{~g} / \mathrm{dl}$. When concomitant hyperphosphatemia was present, instead of sodium ferrous citrate, $1500 \mathrm{mg} /$ day of ferric citrate hydrate was administered. Changes in hemoglobin levels, dose of continuous erythropoietin receptor activator (C.E.R.A.) (administered every 2 weeks) or darbepoetin alfa (every week), and ESA resistance (the ratio of dose of C.E.R.A. or darbepoetin alfa for 4 weeks/hemoglobin $(\mathrm{Hb})$ levels) were compared retrospectively for 28 weeks. As a rule, darbepoetin alfa was administered for patients requiring a low dose (less than $50 \mu \mathrm{g} / 4$ weeks) of ESA and C.E.R.A. for patients requiring higher doses. In 2012, we changed the iron supplementation policy for our hemodialysis patients from the IV to oral route. All the patients receiving sodium ferrous citrate or ferric citrate hydrate were treated after January 2012, during which period the oral iron supplementation policy was applied. As a reference, data of patients receiving IV iron were collected retrospectively: in 22 of 40 being obtained before we changed the iron supplementation policy for hemodialysis patients from the IV to oral route; in 18 of 40 being obtained from the patients after January 2012 who refused oral iron therapy; had a history of side effects from sodium ferrous citrate; or were suspected of poor drug compliance. As IV iron, $40 \mathrm{mg}$ of ferric oxide saccharate was administered ten times consecutively. Patients with blood transfusion or iron supplementation within 3 months before IV iron therapy was initiated were excluded. Figure 1 shows the study design and Table 1 shows baseline characteristics of the patients. We evaluated the effect of oral iron supplementation on anemia by comparing when iron is administered intravenously. Furthermore, we compared the effect of iron therapy on anemia according to the serum ferritin level: less than $100 \mathrm{ng} / \mathrm{ml}$ and between 100 and $199 \mathrm{ng} / \mathrm{ml}$.

\section{Statistical analysis}

Data were expressed as mean \pm standard deviation. Differences in quantitative variables and categorical variables between three groups were compared by a $t$ test and $x^{2}$ test, respectively. Intergroup comparisons of repeatedly measured data in Fig. $3 \mathrm{a}-\mathrm{c}$ were examined by repeated measures of analysis of variance (ANOVA). Statistical significance is defined as $p$ less than 0.05. All statistical analyses were conducted using SPSS (version 19, Chicago, IL, USA).

\section{Results}

As shown in Fig. 2, mean hemoglobin levels increased uniformly in each of the IV, sodium ferrous citrate, and ferric citrate hydrate groups. The peak hemoglobin levels were noted at 10,16, and 10 weeks, respectively, and after that, hemoglobin levels were controlled between 10 and $11 \mathrm{~g} / \mathrm{dl}$ in each group. The control of hemoglobin levels after the steep increase in hemoglobin levels by iron administration was managed by a reduction of the ESA dose. ESA dose reduction at the end of the study in patients receiving IV iron, sodium ferrous citrate, and ferric citrate hydrate were $12.2,33.8$, and $39.5 \%$,
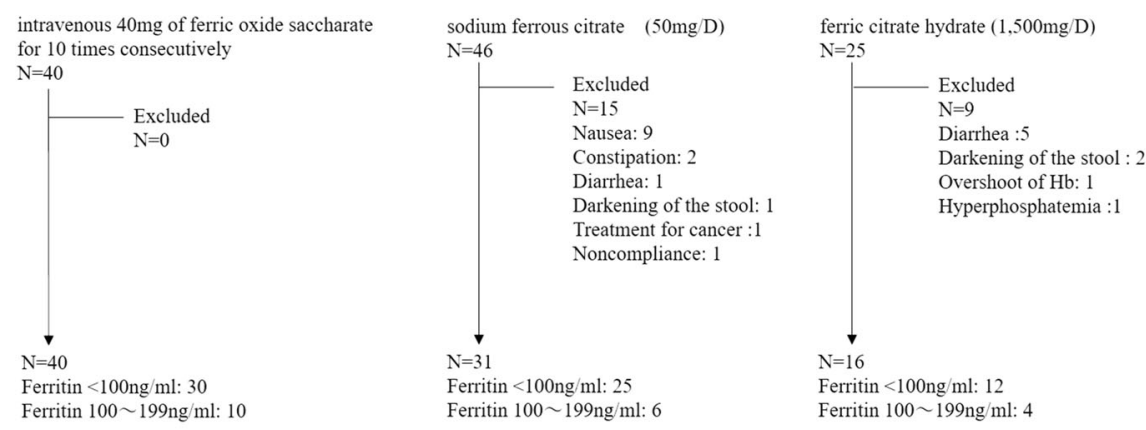

No patients had been given either iron or blood transfusions for more than three months at entry, and continuous erythropoietin receptor activator (C.E.R.A.) or darbepoetin alfa was administered every two or every week respectively.

Fig. 1 Study design. No patients had been given either iron or blood transfusions for more than 3 months before entry, and continuous erythropoietin receptor activator (C.E.R.A.) or darbepoetin alfa was administered every 2 weeks and every week, respectively 
Table 1 Baseline characteristics of the patients

\begin{tabular}{|c|c|c|c|c|c|c|c|c|c|}
\hline & IV iron & $\begin{array}{l}\text { Sodium ferrous } \\
\text { citrate }\end{array}$ & Ferric citrate hydrate & IV iron & $\begin{array}{l}\text { Sodium ferrous } \\
\text { citrate }\end{array}$ & Ferric citrate hydrate & IV iron & Sodium ferrous citrate & Ferric citrate hydrate \\
\hline & All & All & All & Serum ferritin & Serum ferritin & Serum ferritin & Serum ferritin & Serum ferritin & Serum ferritin \\
\hline & & & & $<100 \mathrm{ng} / \mathrm{ml}$ & $<100 \mathrm{ng} / \mathrm{ml}$ & $<100 \mathrm{ng} / \mathrm{ml}$ & $100 \sim 199 \mathrm{ng} / \mathrm{ml}$ & $100 \sim 199 \mathrm{ng} / \mathrm{ml}$ & $100 \sim 199 \mathrm{ng} / \mathrm{ml}$ \\
\hline $\bar{N}$ & 40 & 31 & 16 & 30 & 25 & 12 & 10 & 6 & 4 \\
\hline Female (\%) & $15(37.5)$ & $3(9.7)^{a}$ & $6(37.5)^{b}$ & $12(40.0)$ & $3(25.0)^{\mathrm{a}}$ & $5(41.7)$ & $3(30.0)$ & $0(0.0)$ & $1(25.0)$ \\
\hline Age (years) & $70.9 \pm 9.2$ & $73.3 \pm 9.6^{\mathrm{a}}$ & $65.5 \pm 10.9^{b}$ & $69.3 \pm 8.5$ & $65.8 \pm 12.1^{\mathrm{a}}$ & $76.0 \pm 5.0^{c}$ & $75.6 \pm 10.2$ & $64.3 \pm 3.7^{\mathrm{a}}$ & $65.3 \pm 15.8$ \\
\hline Duration on dialysis (months) & $87.5 \pm 104.7$ & $43.5 \pm 58.3^{\mathrm{a}}$ & $80.1 \pm 107.2$ & $92.2 \pm 101.4$ & $39.2 \pm 51.6^{\mathrm{a}}$ & $80.5 \pm 120.3$ & $73.4 \pm 118.6$ & $61.3 \pm 84.7$ & $79.0 \pm 66.0$ \\
\hline Diabetes (\%) & $15(37.5)$ & $17(54.8)$ & $8(50.0)$ & $10(33.3)$ & $14(56.0)$ & $6(50.0)$ & $5(50.0)$ & $3(50.0)$ & $2(50.0)$ \\
\hline Hemoglobin $(\mathrm{g} / \mathrm{dl})$ & $9.8 \pm 0.9$ & $9.6 \pm 1.2$ & $10.0 \pm 1.2$ & $9.7 \pm 0.9$ & $9.8 \pm 1.2$ & $9.8 \pm 1.1$ & $10.0 \pm 0.5$ & $8.9 \pm 1.1^{\mathrm{a}}$ & $10.8 \pm 1.5^{\mathrm{b}}$ \\
\hline ESAs ( $\mu \mathrm{g} / 4$ weeks) & $104.6 \pm 44.0$ & $116.0 \pm 44.6$ & $101.9 \pm 43.1$ & $109.3 \pm 45.5$ & $120.6 \pm 46.3$ & $112.5 \pm 43.3$ & $90.5 \pm 37.5$ & $96.7 \pm 32.7$ & $70.0 \pm 24.5$ \\
\hline C.E.R.A. (N) & 34 & 24 & 15 & 27 & 21 & 11 & 7 & 3 & 4 \\
\hline Darbepoetin alfa $(N)$ & 6 & 7 & 1 & 3 & 4 & 1 & 3 & 3 & 0 \\
\hline CRP $(\mathrm{mg} / \mathrm{dl})$ & $0.18 \pm 0.24$ & $0.27 \pm 0.45$ & $0.31 \pm 0.63$ & $0.18 \pm 0.26$ & $0.20 \pm 0.35$ & $0.19 \pm 0.31$ & $0.17 \pm 0.16$ & $0.57 \pm 0.69$ & $0.68 \pm 1.17$ \\
\hline Serum alb (g/dl) & $3.5 \pm 0.3$ & $3.6 \pm 0.3$ & $3.7 \pm 0.2$ & $3.6 \pm 0.3$ & $3.6 \pm 0.3$ & $3.6 \pm 0.2$ & $3.5 \pm 0.2$ & $3.6 \pm 0.5$ & $3.8 \pm 0.3$ \\
\hline$p(\mathrm{mg} / \mathrm{dl})$ & $4.8 \pm 1.0$ & $5.0 \pm 1.1$ & $5.6 \pm 1.3^{\mathrm{a}}$ & $4.9 \pm 1.1$ & $5.1 \pm 1.1$ & $5.4 \pm 1.2$ & $4.6 \pm 0.8$ & $4.7 \pm 0.7$ & $6.3 \pm 1.3^{a, b}$ \\
\hline Intact PTH (pg/ml) & $173.6 \pm 95.1$ & $179.4 \pm 115.3$ & $160.8 \pm 148.8$ & $171.2 \pm 103.5$ & $156.1 \pm 77.3$ & $172.8 \pm 168.1$ & $180.8 \pm 67.6$ & $276.3 \pm 192.4$ & $124.5 \pm 68.8$ \\
\hline Ferritin (ng/ml) & $79.4 \pm 45.3$ & $65.1 \pm 35.7$ & $74.4 \pm 43.8$ & $57.8 \pm 25.2$ & $51.3 \pm 22.2$ & $52.8 \pm 20.4$ & $144.4 \pm 24.0$ & $122.4 \pm 19.9$ & $139.1 \pm 25.3$ \\
\hline $\mathrm{Fe}(\mu \mathrm{g} / \mathrm{dl})$ & N.A. & $76.5 \pm 23.4$ & $73.3 \pm 31.6$ & N.A. & $80.4 \pm 22.3$ & $75.6 \pm 33.0$ & N.A. & $60.2 \pm 22.5$ & $66.8 \pm 31.1$ \\
\hline
\end{tabular}

\section{N.A. not available}

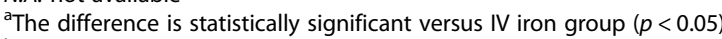

${ }^{\mathrm{b}}$ The difference is statistically significant versus sodium ferrous citrate group $(p<0.05)$

The difference is statistically significant versus sodium ferrous citrate group $(p<0.001)$ 


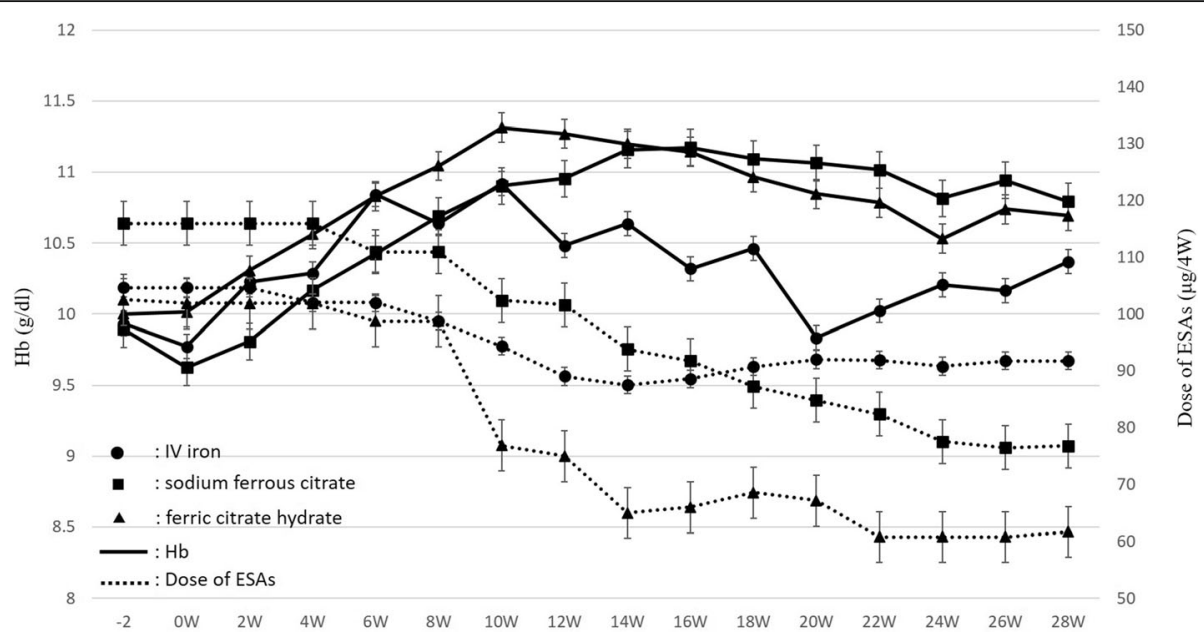

Fig. 2 Hemoglobin levels and dose of ESAs (C.E.R.A. or darbepoetin alfa) per 4 weeks during the study period. Data are expressed as mean \pm SE

respectively. To compare the erythropoietic effect of iron administration under the simultaneous changes of hemoglobin levels and ESA dose, we evaluated the ratio of ESA dose for 4 weeks/Hb levels. In the first 10 weeks, $\mathrm{ESA} / \mathrm{Hb}$ ratio decreased uniformly in the three groups but then started to increase in the IV group, whereas it decreased further in the sodium ferrous citrate and ferric citrate hydrate groups. At the end of study, ESA/Hb reduction ratios in patients receiving intravenous iron, sodium ferrous citrate, and ferric citrate hydrate were $10.3,34.5$, and $37.4 \%$, respectively (Fig. 3a). In patients with ferritin levels $<100 \mathrm{ng} / \mathrm{ml}$ at the beginning of the study (Fig. 3b), ESA/Hb ratio decreased more by oral than IV iron $(p<0.05)$. By the multiple comparison of the groups, the ferric citrate hydrate group but not the sodium ferrous citrate group showed a significant tendency to decrease the ESA/Hb ratio as compared with the IV iron group $(p<0.05)$. In patients with ferritin levels $100 \sim 199 \mathrm{ng} / \mathrm{ml}$ at the beginning of the study, $\mathrm{ESA} / \mathrm{Hb}$ ratio did not change with iron administration regardless of whether the IV or oral route was used (Fig. 3c). Table 2 shows the serum ferritin levels during the study. Serum ferritin levels at 24 weeks were almost the same as compared to those at 12 weeks in the IV iron group, while on the other hand, serum ferritin levels at 24 weeks were higher than those at 12 weeks in the oral iron groups.

\section{Discussion}

After the introduction of ESAs for the treatment of hemodialysis patients, iron deficiency became an important underlying component of anemia in hemodialysis patients [3]. Although oral iron supplementation is supposed to be more physiologic than the IV one, oral iron absorption is appreciable when serum ferritin concentration is less than 70 to $100 \mathrm{ng} / \mathrm{ml}$ and decreases when this exceeds
$300 \mathrm{ng} / \mathrm{ml} \mathrm{[11].} \mathrm{Numerous} \mathrm{studies} \mathrm{have} \mathrm{evaluated} \mathrm{oral}$ iron administration in hemodialysis patients, and overall, oral iron is not superior to IV iron $[6,7,12]$, and thus, IV administration has been recommended [8, 9]. Although, compared with IV iron therapy, there is scarce evidence regarding the efficacy of oral iron for the treatment of anemia in hemodialysis patients, we obtained favorable effects with oral iron therapy. Possible explanations for this discrepancy include the following. In our study, the effectiveness of oral iron was recognized only in patients with serum ferritin levels less than $100 \mathrm{ng} / \mathrm{ml}$ at baseline and not in patients with higher ferritin levels. On the other hand, the mean serum ferritin levels in patients receiving oral iron reported by Fishbane et al. [6] and MacDougall et al. [7] were 178.9 and $309 \mathrm{ng} / \mathrm{ml}$, respectively, and the former failed to demonstrate any efficacy of oral iron (ferrous sulfate or iron polysaccharide), while in the latter, although oral iron (ferrous sulfate) could increase hemoglobin levels with almost the same dose of ESA, serum ferritin levels decreased and efficacy was inferior to IV iron. These results indicate that oral iron therapy is effective predominantly in patients with low serum ferritin levels, with $100 \mathrm{ng} / \mathrm{ml}$ being a tentative border line to predict the efficacy of oral iron therapy.

Ferritin, together with transferrin saturation, is the recommended test to assess iron stores in dialysis patients [13]. IV iron administration is recommended when serum ferritin levels are less than $100 \mathrm{ng} / \mathrm{ml}$ in Japan [9], in contrast to $300 \mathrm{ng} / \mathrm{ml}$ in the European Best Practice (ERBP) group [14] and $500 \mathrm{ng} / \mathrm{ml}$ in the Kidney Disease: Improving Global Outcomes (KDIGO) [13]. Recently, there has been a tendency to increase the IV iron dose and mean serum ferritin levels of hemodialysis patients in many countries [15]. In the USA, the US Centers for Medicare and Medicaid Services instituted a partially capitated payment system for dialysis services that included both ESAs 


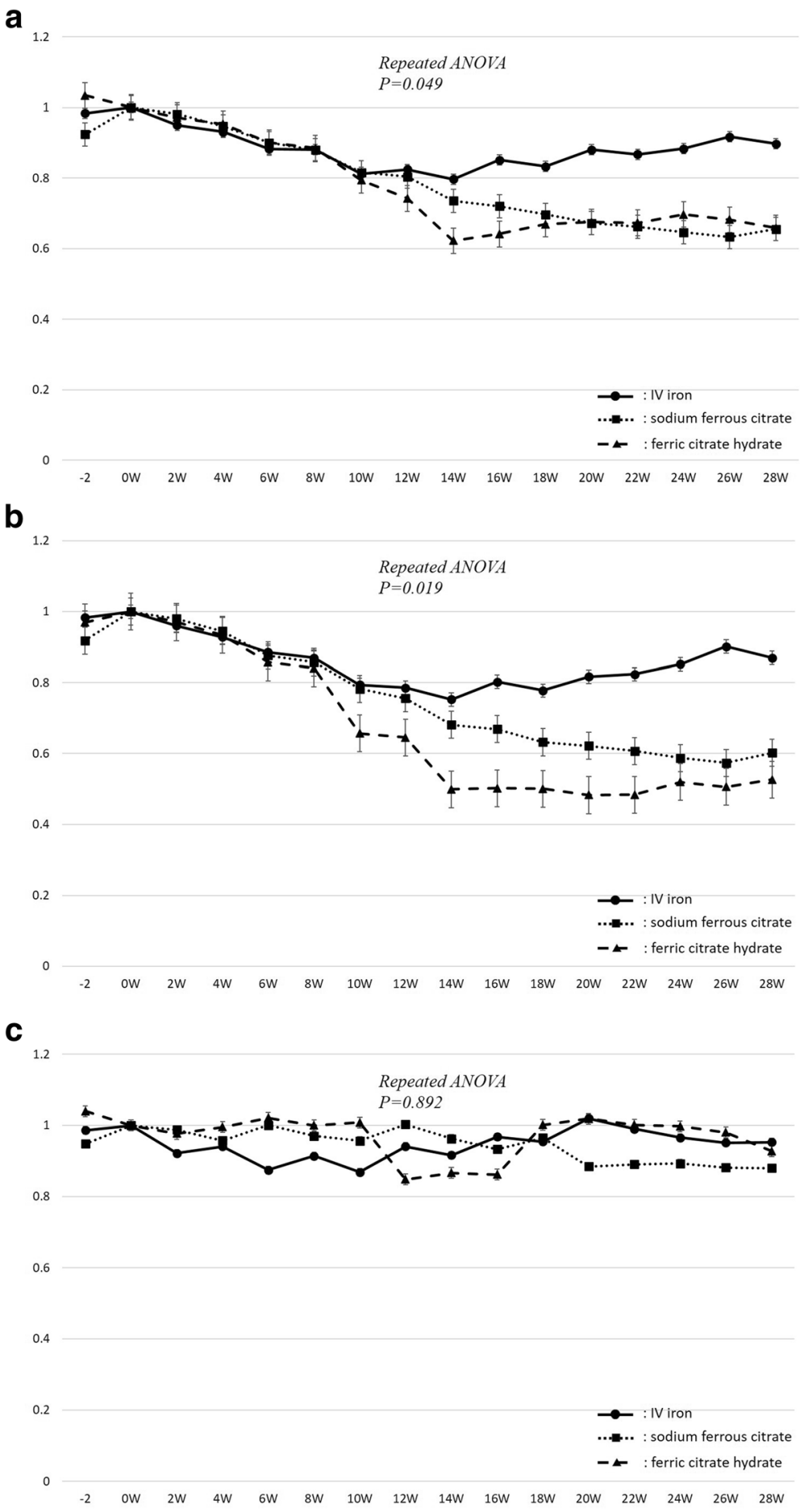

Fig. 3 a Ratio of dose of ESAs per 4 weeks/Hb during the study period (OW: reference). Data are expressed as mean \pm SE. $\mathbf{b}$ Ratio of dose of ESAs per 4 weeks/Hb during the study period in patients with serum ferritin levels $<100 \mathrm{ng} / \mathrm{ml}$ at baseline (OW: reference). Data are expressed as mean \pm SE. c Ratio of dose of ESAs per 4 weeks/Hb during the study period in patients with serum ferritin levels 100 199 $\mathrm{ng} / \mathrm{ml}$ at baseline (OW: reference). Data are expressed as mean $\pm \mathrm{SE}$

and IV iron in 2011, which further increased the use of low-cost IV iron and decreased the dose of high-cost ESAs, with the mean serum ferritin concentration exceeding $800 \mathrm{ng} / \mathrm{ml}$ in 2013 [16, 17]. A considerable variation in serum ferritin levels in hemodialysis patients is seen in individual countries [15], $144.49 \pm 261.83 \mathrm{ng} / \mathrm{ml}$ 
Table 2 Serum ferritin levels during the study period

\begin{tabular}{|c|c|c|c|c|c|c|c|c|c|}
\hline & IV iron & $\begin{array}{l}\text { Sodium ferrous } \\
\text { citrate }\end{array}$ & Ferric citrate hydrate & IV iron & $\begin{array}{l}\text { Sodium ferrous } \\
\text { citrate }\end{array}$ & Ferric citrate hydrate & IV iron & Sodium ferrous citrate & Ferric citrate hydrate \\
\hline & \multirow[t]{2}{*}{ All } & \multirow[t]{2}{*}{ All } & \multirow[t]{2}{*}{ All } & Serum ferritin & Serum ferritin & Serum ferritin & Serum ferritin & Serum ferritin & Serum ferritin \\
\hline & & & & $<100 \mathrm{ng} / \mathrm{ml}$ & $<100 \mathrm{ng} / \mathrm{ml}$ & $<100 \mathrm{ng} / \mathrm{ml}$ & $100 \sim 199$ ng/ml & $100 \sim 199$ ng/ml & $100 \sim 199$ ng/ml \\
\hline N & 40 & 31 & 16 & 30 & 25 & 12 & 10 & 6 & 4 \\
\hline 0 weeks & $79.4 \pm 45.3$ & $65.1 \pm 35.7$ & $74.4 \pm 43.8$ & $57.7 \pm 25.2$ & $51.3 \pm 22.2$ & $52.8 \pm 20.4$ & $144.4 \pm 24.0$ & $122.4 \pm 19.9$ & $139.1 \pm 25.3$ \\
\hline 12 weeks & $92.9 \pm 48.7$ & $112.6 \pm 56.4$ & $128.9 \pm 78.7$ & $92.9 \pm 48.7$ & $98.5 \pm 39.3$ & $91.3 \pm 48.0$ & N.A. & $196.8 \pm 76.3$ & $232.4 \pm 42.5$ \\
\hline 24 weeks & $109.5 \pm 71.3$ & $140.9 \pm 60.5$ & $159.5 \pm 57.3^{\mathrm{a}}$ & $82.0 \pm 41.8$ & $130.7 \pm 57.3^{b}$ & $153.6 \pm 59.5^{c}$ & $164.5 \pm 87.5$ & $181.6 \pm 60.2$ & $189.0 \pm 46.7$ \\
\hline
\end{tabular}

N.A. not available

${ }^{\text {aT }}$ The difference is statistically significant versus IV iron group $(p<0.05)$

${ }^{\mathrm{b}}$ The difference is statistically significant versus IV iron group $(p<0.005)$

'The difference is statistically significant versus IV iron group $(p<0.001)$ 
in 2012 in Japan [18] which is the lowest in the countries participating in the Dialysis Outcomes and Practice Pattern Study (DOPPS). Lower ferritin levels in hemodialysis patients in Japan than in those in western countries which are proportional to IV iron dose [15] and low serum ferritin levels (median $72 \mathrm{ng} / \mathrm{ml}$ ) in hemodialysis patients administered predominantly oral rather than IV iron reported from Canada [10] suggest that without IV iron administration, serum ferritin levels are low in many hemodialysis patients. The fact that with the oral iron supplementation policy which was initiated when serum ferritin levels are less than $200 \mathrm{ng} / \mathrm{ml}$ (in majority of them less than $100 \mathrm{ng} / \mathrm{ml}), 80 \%$ of hemodialysis patients in our clinic receive oral iron also proves this.

Although iron is essential for hematopoiesis, the IV route bypasses regulation of iron absorption in the duodenum and intestine. It is speculated that nonphysiologic iron supplementation by IV iron easily increases the plasma nontransferrin-bound iron, which is readily accumulated in the liver and the reticuloendothelial system and increases iron stores. This induces hepcidin synthesis and limits further enteral iron absorption and release of iron from iron stores [19]. In this situation, oral iron therapy is less likely to be effective, which is supposed to be usual in patients receiving high-dose IV iron administration.

As an IV iron therapy, $40 \mathrm{mg}$ of ferric oxide saccharate was administered ten times consecutively in our study, but this represents a relatively small dose and short duration of treatment and this may be the reason why the efficacy of IV iron ceased at around 16 weeks and also may be the reason for the lack of any apparent effect of IV iron in patients with serum ferritin levels 100 199 $\mathrm{ng} / \mathrm{ml}$ at baseline. In one patient with IV iron therapy, serum ferritin levels were investigated frequently and showed that with a rapid increase in hemoglobin levels, in contrast, serum ferritin levels decreased and returned to the same level before IV iron at 16 weeks (data not shown). Changes in serum ferritin levels during the study (Table 2) also suggest the possibility of an insufficient dose of IV iron in this study. Nevertheless, in practice after changing the iron supplementation policy for hemodialysis patients from the IV to oral route, the ESA dose was halved with mean hemoglobin levels kept between 10.0 and $11.0 \mathrm{~g} / \mathrm{dl}$ (data not shown). This proves the efficacy of oral iron in hemodialysis patients with low serum ferritin levels.

Regarding the study period, compared with our study, the observation periods of Fishbane et al. [6] and MacDougall et al. [7] were relatively short, 4 months and 16 weeks, respectively. Furthermore, Umanath et al. reported that serum ferritin levels increased through week 24, remaining relatively stable thereafter in hemodialysis patients treated with ferric citrate [20], which is in accordance with the information provided by pharmaceutical companies in Japan; it takes approximately 24 weeks by the time serum ferritin levels reach a plateau in patients receiving ferric citrate hydrate or sucroferric oxyhydroxide (data not shown). In our study, it took 24 weeks by the time ESA/Hb ratio reached plateaus in the oral iron groups (Fig. 3) and serum ferritin levels at 24 weeks were even higher than those at 12 weeks (Table 2) consistent with the above results. These results mean that it takes around half a year by the time oral iron exerts its maximum erythropoietic effect, while in patients receiving IV iron therapy, it takes a shorter time.

Our results suggest that for hemodialysis patients with serum ferritin levels less than $100 \mathrm{ng} / \mathrm{ml}$, oral iron therapy can decrease the needed ESA dose which is equivalent or superior to that by IV iron. Moreover, although long-term safe range of serum ferritin levels is not known, oral iron therapy may also help to avoid iron toxicity and reduce the morbidity related to iron overload.

Although usually not severe, oral iron therapy has relatively frequent side effects including nausea, diarrhea, and constipation. From the standpoint of its efficacy as iron supplementation, oral instead of IV iron therapy is warranted for patients with serum ferritin levels less than $100 \mathrm{ng} / \mathrm{ml}$ and without side effects induced by oral iron therapy. On the other hand, in patients whose serum ferritin levels are never under $100 \mathrm{ng} / \mathrm{ml}$, the absorption and utilization of oral iron are limited and in this situation, the use of a high dose of IV instead of oral iron may be warranted. However, because of the small number of patients; heterogeneity of distribution of age, sex, and $\mathrm{Hb}$ levels between groups; and retrospective nature of our study, our results cannot yet be considered conclusive. But in the meantime, our results suggest that for hemodialysis patients with ferritin levels less than $100 \mathrm{ng} / \mathrm{ml}$, oral iron supplementation is an effective and likely safe method for the treatment of anemia and can decrease the ESA dose and may help to avoid iron toxicity.

\section{Conclusions}

Oral iron therapy without the use of IV iron is effective for the treatment of anemia in hemodialysis patients with low serum ferritin levels.

\section{Abbreviations \\ C.E.R.A.: Continuous erythropoietin receptor activator; EPO: Erythropoietin; ESA: Erythropoietin-stimulating agent; Hb: Hemoglobin; IV: Intravenous}

\section{Acknowledgements \\ The authors thank all the staff members working at Daimon Clinic for Internal Medicine, Nephrology and Dialysis.}

Funding

There is no funding to be disclosed. 


\section{Availability of data and materials}

The datasets during and/or analyzed during the current study are available from the corresponding author on reasonable request.

\section{Authors' contributions}

IM was involved in the statistical analysis. Both authors read and approved the final manuscript.

\section{Competing interests}

The authors declare that they have no competing interests.

\section{Consent for publication}

Not applicable.

\section{Ethics approval and consent to participate}

This study was approved by the local ethics committee (issue 2015-A1 at Daimon Clinic for Internal Medicine, Nephrology and Dialysis), and written informed consent was obtained from all patients.

\section{Author details}

${ }^{1}$ Department of Nephrology, Daimon Clinic for Internal Medicine, Nephrology and Dialysis, Oshino 1-400, Nonoichi 921-8802, Japan. ${ }^{2}$ Division of Rheumatology, Department of Internal Medicine, Kanazawa University Graduate School of Medicine, Kanazawa, Japan.

Received: 26 July 2016 Accepted: 18 October 2016

Published online: 28 November 2016

\section{References}

1. McGonigle RJ, Wallin JD, Shadduck RK, Fisher JW. Erythropoietin deficiency and inhibition of erythropoiesis in renal insufficiency. Kidney Int. 1984:25:437-44.

2. Kidney Disease Improving Global Outcomes (KDIGO). Clinical practice guideline for anemia in chronic kidney disease. Kidney Int. 2012;Suppl 2:292-8.

3. Eschbach JW, Egrie JC, Downing MR, Browne JK, Adamson JW. Correction of the anemia of end-stage renal disease with recombinant human erythropoietin. N Engl J Med. 1987;316:73-8.

4. Kuragano T, Matsumura O, Matsuda A, et al. Association between hemoglobin variability, serum ferritin levels, and adverse events/mortality in maintenance hemodialysis patients. Kidney Int. 2014;86:845-54.

5. Bailie GR, Larkina M, Goodkin DA, et al. Data from the Dialysis Outcomes and Practice Pattern Study validate an association between high intravenous iron doses and mortality. Kidney Int. 2015;87:162-8.

6. Fishbane S, Frei GL, Maesaka J. Reduction in recombinant human erythropoietin doses by the use of chronic intravenous iron supplementation. Am J Kidney Dis. 1995;26:41-6.

7. MacDougall IC, Tucker B, Thompson J, Tomson CRV, Baker LRI, Raine EG. A randomized controlled study of iron supplementation in patients treated with erythropoietin. Kidney Int. 1996;50:1694-9.

8. KDOQI. K.DOQI clinical practice guidelines and clinical recommendation for anemia in chronic kidney disease. Am J Kidney Dis. 2006;47 Suppl 3:S58-70.

9. Tsubakihara Y, Nishi S, Akiba T, et al. 2008 Japanese Society for dialysis therapy: guidelines for renal anemia in chronic kidney disease. Ther Apher Dial. 2010;14:240-75.

10. Lenga I, Lok C, Marticorena R, Hunter J, Dacouris N, Goldstein M. Role of oral iron in the management of long-term hemodialysis patients. Clin J Am Soc Nephrol. 2007;2:688-93.

11. Eschbach JW, Cook JD, Scribner BH, Finch CA. Iron balance in hemodialysis patients. Ann Intern Med. 1977:87:710-3.

12. Wingard RL, Parker RA, Ismail N, Hakim RM. Efficacy of oral iron therapy in patients receiving recombinant human erythropoietin. Am J Kidney Dis. 1995;25:433-9.

13. Kidney Disease Improving Global Outcomes. KDIGO clinical practice guideline for anemia in chronic kidney disease: summary of recommendation statements. Kidney Int Suppl. 2012;2:283-7.

14. Locatelli F, Bárány $P$, Covic A, et al. Kidney disease: improving global outcomes guidelines on anaemia management in chronic kidney disease: a European renal best practice position statement. Nephrol Dial Transplant. 2013;28:1346-59.
15. Bailie GR, Larkina M, Goodkin DA, et al. Variation in intravenous iron use internationally and over time: the Dialysis Outcomes and Practice Pattern Study (DOPPS). Nephrol Dial Transplant. 2013;28:2570-9.

16. Weiner DE, Winkelmayer WC. Commentary on 'The DOPPS practice monitor for U.S. dialysis care: update on trends in anemia management 2 years into the bundle': iron(y) abounds 2 years later. Am J Kidney Dis. 2013;62:1217-20.

17. Charytan DM, Pai AB, Chan CT, on behalf of the Dialysis Advisory Group of the American Society of Nephrology, et al. Considerations and challenges in defining optimal iron utilization in hemodialysis. J Am Soc Nephrol. 2015;26:1238-47.

18. Nakai S, Hanafusa N, Masakane I, et al. An overview of regular dialysis treatment in Japan (as of 31 December 2012). Ther Apher Dial. 2014;18:535-602.

19. Young B, Zaritsky J. Hepcidin for clinicians. Clin J Am Soc Nephrol. 2009:4:1384-7.

20. Umanath K, Jalal DI, Greco BA, et al. Ferric citrate reduces intravenous iron and erythropoiesis-stimulating agent use in ESRD. J Am Soc Nephrol. 2015;26:2578-87.

\section{Submit your next manuscript to BioMed Central and we will help you at every step:}

- We accept pre-submission inquiries

- Our selector tool helps you to find the most relevant journal

- We provide round the clock customer support

- Convenient online submission

- Thorough peer review

- Inclusion in PubMed and all major indexing services

- Maximum visibility for your research

Submit your manuscript at www.biomedcentral.com/submit
) Biomed Central 